\title{
REDUCING THE LATERAL DISPLACEMENT OF LEAD RUBBER BEARING ISOLATORS UNDER THE NEAR FIELD EARTHQUAKES BY CROSSWISE DISSIPATERS CONNECTED TO RIGID SUPPORT STRUCTURE
}

\author{
Kourosh Talebi Jouneghani ${ }^{1}$, Mahmood Hosseini ${ }^{2}$, Mohammad Sadegh Rohanimanesh ${ }^{3}$ \\ and Morteza Raissi4
}

1. Department of Civil Engineering, Central Tehran Branch, Islamic Azad University, Tehran, Iran; kou.talebijouneghani.eng@iauctb.ac.ir

2. Department of Civil Engineering, Faculty of Engineering, Eastern Mediterranean University (EMU), Famagusta 99628, North Cyprus via Mersin 10, Turkey; mahmood.hosseni@emu.edu.tr

3. Department of Civil Engineering, Central Tehran Branch, Islamic Azad University, Tehran, Iran; m.s.rohanimanesh@iauctb.ac.ir

4. Department of Civil Engineering, University of Science and Technology (IUST), Tehran, Iran; mraissi@iust.ac.ir

\begin{abstract}
The purpose of base isolation is to absorb earthquake energy, prolong the life of the structure, and enable the structure to be similar to a rigid body. However, since resonance can occur due to the closeness of the period of structures to the long period and large velocity pulses of the near field earthquakes, the stability of these buildings greatly reduces, and with the large displacement above isolation level, sometimes, tendency of overturning is created in isolators leading to their destruction. The main objective of this study is to significantly reduce the lateral displacement of base isolation subjected to near field earthquakes. In this research, seismic response calculation has been carried out for five steel moment frame structure with the $3,5,8,11$, and 14 stories in two states of with and without stiff core structure and energy dissipaters. The analyses has been done under fourteen scaled records of seven near-source and seven far-source earthquakes. It has been shown that the lateral displacement of base isolation system can be reduced by $87 \%$ for low-rise buildings, and $77 \%$ for high-rise buildings.
\end{abstract}

\section{KEYWORDS}

Reduction of lateral displacement, Base isolation, Near field earthquake, Long period large velocity pulse, Stiff support structure, Energy dissipater

\section{INTRODUCTION}

Based on the official records, many buildings collapse due to major earthquakes, and more importantly, due to the lack of having appropriate earthquake-resistant designs. Mortality rates due to earthquakes can be significantly restrained if buildings are equipped with suitable earthquakeresistant designs which mainly rely on the ductile behavior of the design. When efforts are made to protect the integrity of the building by boosting the stiffness, unluckily, the acceleration of floors can rise successively leading to the destruction of the building.

Seismic isolation has arisen as an alternate earthquake-resistant design method. This method has increasingly become popular since it offers to protect both structural and non-structural mechanisms and the contents of a building. Hence, seismic isolation attempts to reduce floor accelerations to focus on limits while keeping base displacements below a reasonable range. This is achieved by 
simultaneously balancing three factors. First, seismic isolation elongates the natural period of the building by using laterally flexible isolation elements. In other words, this reduces spectral accelerations and thus the effective seismic forces. Second, the isolation system allows the superstructure to move flexibly that offers rigid-body motion decreasing inter-story drift ratios. Third, the system provides damping via the isolation elements. This causes dissolving the energy input from the earthquake and is particularly indispensable in restraining the base displacements.

The effects of earthquakes have been investigated both near and far from the faults. Primarily, nearfield earthquakes were defined by Bolt [1] in 1975. According to Bolt, if the earthquake occurs in the vicinity of a site, it is considered a near-field earthquake. Hence, the distance of the center of the earthquake from the site is vital for the classification; for instance, Bolt [1] stated that if the site is within a radius of $15 \mathrm{~km}$ of the fault, the earthquake is classified as near-field. These types of ground motions are essentially famous for their critical energy pulses. In spite of the small magnitude of near-field earthquakes, they carry tremendous destructive potential. As these earthquakes take place in the vicinity of an active fault, they have long-period pulse maps [2]. A thorough investigation of the main parameters of near-field earthquakes for concrete structures has been carried out by Talebi Jouneghani et al. [3].

Comprehensive studies have been carried out to address the main concerns on seismic isolation within the last decades [3-22]. These studies show an accurately designed seismic isolation system effectively diminishes floor accelerations and inter-story drift ratios to acceptable levels without triggering unsatisfactorily large base displacements in case of far-field earthquakes. However, regarding near-field pulse-like earthquakes, the isolation system performs poorly, and researchers are still in dispute whether this system is appropriate for the mentioned situation.

Lu et al. [4] experimentally investigated sliding isolation systems. They reported when the isolation period is close enough to the pulse period, resonance-like behavior is more likely caused. To tackle this problem, the utilization of high damping at the isolation system was pursued to reduce excessive base displacements. However, other problems were caused by using high damping at the isolation systems. By utilizing a two degree of freedom model, Kelly [5] revealed that using additional damping could substantially reduce excessive base displacement; however, this causes the enhancement in inter-story drifts and floor acceleration. Jangid and Kelly [6] showed a similar result, but floor accelerations suddenly increase in isolation damping leading to transmit higher accelerations into superstructure when subjected to near-field earthquakes. Hall [7] showed that by utilizing an "optimum" amount of excessive damping, it is possible to reduce base displacements without expanding floor acceleration or understory drifts afterward. Alhan and Gavin [8] proved that an optimum mix of isolation stiffness and damping to certain levels could be achieved to decrease base displacements without significantly enhancing floor accelerations in an 8-story building.

Alhan and Guvin [9] examined the reliability of the floor isolation system to protect vibrationsensitive equipment in a probabilistic study. The results indicated it could not save the structures in the close area of the fault. In another research, Jangid [10] has investigated the seismic response of shear-type multi-story buildings equipped with lead-rubber bearings under near-field effects. They observed that the lead rubber bearings with higher yield displacement, which is soft bearings, have a better performance than the bearings with low yield displacement in the case of near-field ground motions. Alhan C and Göktas Y. [11] investigated the near-field earthquake records. A significant difference was observed when comparing far-field and near-field earthquake records in terms of long velocity pulses and large vertical acceleration. As a result of the proximity and the long-term periodicity of pulses to the period of structures in this area, destructive shocks are caused in the buildings with base isolation. Recently, the effects of near field ground motions on the base-isolated buildings were assessed by Providakis [12]. In his study, the base-isolated structures were equipped with lead rubber and friction pendulum bearings along with supplemental damping. He showed although the use of supplemental damping in limiting the absolute floor accelerations for both lead rubber bearing and friction pendulum system isolators in cases of near-field earthquake motions are effective, the absolute floor accelerations of the investigated types of lead rubber bearing and friction 
pendulum system isolated buildings under specific far-field motions increases. Other studies [11, 1314] demonstrated that floor acceleration could enhance if seismically isolated structures were exposed to near field earthquakes with a pulse period close to their solution period. They also suggested additional base displacements in case of near field earthquake probably result in the pounding of the seismically isolated building provided that the isolation system displacement surpasses the seismic gap left around it. Moreover, it was observed that substantial increases in floor acceleration are caused by such a pounding [15]. Likewise, Taflanidis and Jia [16] conducted the most dangerous base-isolated structures supplied unit lead rubber bearing through a proposed simulation-based framework. They demonstrated that the seismic risk test in their work. The study revealed that when the deformation of bearings exceeds the isolation gap, the seismic risk amplifies. It was recently revealed by Mazza and Vulcano [17] and Mazza et al. [18] that the isolators might even take tensile loads when vertical components of near-field earthquakes with high peak values are in question with a possible failure of isolation system caused by high seismic displacement demands. Alhan and Sahin [19] investigated the role of isolator characteristics in reducing the floor accelerations of seismically isolated buildings with flexible superstructures under near-field earthquakes. They found that higher isolation damping would decrease floor accelerations up to the creation point, but further increases in isolation damping may cause higher floor accelerations.

In another study, Mazza and Vulcano [20] proved that supplemental damping is crucial to control the base displacements of seismically isolated buildings. However, it may not guarantee better performance in terms of structural and non-structural damage subjected to near-field earthquakes. In addition, for relatively short pulse periods, some undesirable results are created. Nigdeli et al. [21] offered a harmony study optimization metrology for seismically isolated buildings subjected to both near-field and far-field earthquakes to optimize isolation system parameters such as isolation period and damping ratio. Alhan and Davas [22] stated that "Benchmark buildings with base isolation systems of different isolation periods and characteristic force ratios are subjected to synthetically developed near-field earthquake records at different fault-distances with different velocity pulse periods, and their seismic performances are reported." In their study, for seismically isolated buildings, protecting vibration-sensitive equipment in operating conditions in case of large magnitude pulse-like near field earthquakes with very long pulse periods is a very challenging task. Furthermore, the ratio of the isolation period to the pulse period has a huge impact on the peak base displacement demands and the peak floor acceleration demands when subjected to long and short pulse periods, respectively. It is reported that the mentioned effect becomes even more tangible for shorter fault-distances and smaller characteristic force ratios.

Responses of base isolation systems subjected to near-field ground motions are one of the well-researched areas. However, researches have indicated that base isolation systems utilized in near-field earthquakes have experienced substantial lateral displacement. Moreover, a large number of structures equipped with base isolation have overturned. Consequently, in this study, a new method is adopted to limit the lateral displacement of base isolation in all types of structures under near-field earthquakes, add more stability to the structure, and reduce the destructive effects of this phenomenon. Furthermore, a support structure with viscous dampers is employed to reduce the effects of the resonance due to near-field earthquakes.

\section{MODULATION}

\section{Design of structures}

As it is shown in Figure 1, five steel moment frame structures of 3, 5, 8, 11, 14 stories with square plans are the designed models, and all of them are equipped with a Chevron brace with a yard for the establishment of supporting structures. All of the structures are designed by the LRFD method in ETABS 2016; later, they are transferred to PERFORM 3D for nonlinear time history analyses. 

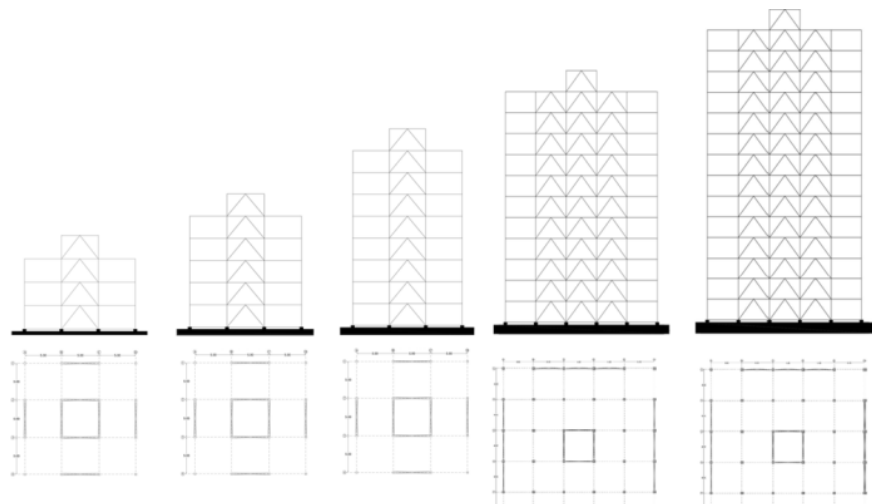

Fig. 1 - Structures without a rigid support

\section{Rigid support structure}

The rigid support structure is a square column situated in the middle of the base structure. The stiffness of this column in all types of structures is the same as the stiffness of the braces in one direction of the same structure. This column is designed in the center of the base, and it is rigidly connected to the foundation. In addition, the structures are connected to the column in the roof by horizontally crosswise viscous dampers, as is shown in Figure 2. It is notable that all of the rigid support structures are designed in PERFORM 3D.

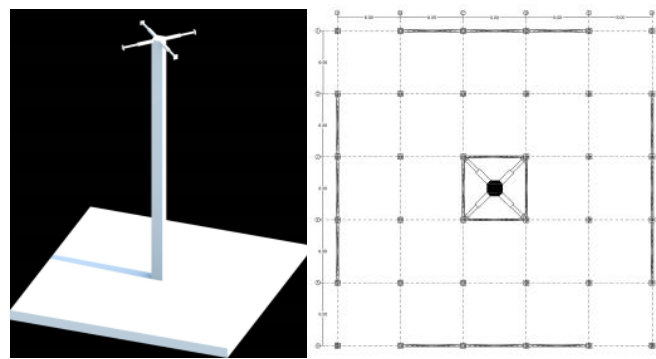

Fig. 2 - Rigid support structure with dampers

\section{Base isolation system}

The base of lead rubber bearing (LRB) isolators is designed based on International Building Code (IBC) [23]. The initial design of the Base isolation is by force-displacement method, in which effective stiffness $\left(K_{e f f}\right)$ is required. As a result, the target period $T_{D}$ can be determined using Equation (1).

$$
T_{D}=2 \pi \sqrt{\frac{W_{t}}{g K_{e f f}}}
$$

In Equation (1), $W_{t}$ is the total weight of the superstructure. Moreover, Equation (2) is used to estimate the displacement of the design.

$$
D_{D}=\frac{g}{4 \pi^{2}} \frac{S_{D 1} T_{D}}{B_{D}}
$$

In Equation (2), $B_{D}$ is the damping factor, and $S_{D 1}$ is the spectral pseudo acceleration obtained from the design spectrum. The parameters selected to define the utilized isolators, lead rubber bearing, in PERFORM 3D are demonstrated in Figure 3 and Table 1. 
$\mathrm{F}(\mathrm{KN})$

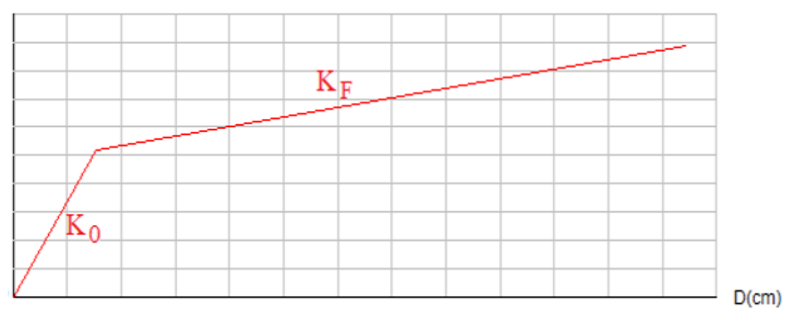

Fig. 3 - Force-displacement relationship for lead rubber bearing
Tab. 1 - Force-displacement relationship for lead rubber bearing

\begin{tabular}{|c|c|c|c|c|}
\hline Structures & $\begin{array}{c}K_{0} \\
(\mathbf{K N})\end{array}$ & $\begin{array}{c}K_{F} \\
(\mathbf{K N})\end{array}$ & $\begin{array}{c}F_{u} \\
(\mathbf{K N})\end{array}$ & $\begin{array}{c}D_{\max } \\
(\mathbf{m})\end{array}$ \\
\hline 3 story & 400 & 40 & 14 & 0.200 \\
\hline 5 story & 485 & 48.5 & 16.5 & 0.225 \\
\hline 8 story & 530 & 53 & 19 & 0.255 \\
\hline 11 story & 605 & 60.5 & 22.5 & 0.311 \\
\hline 14 story & 675 & 67.5 & 26 & 0.311 \\
\hline
\end{tabular}

\section{The fluid viscous damper system}

According to the Iranian manual for structural damping systems in the design and retrofitting of buildings [24], the force in the viscous damper is calculated using Equation 3.

$$
F=C_{o}|\dot{D}|^{\alpha} \operatorname{sgn}[\dot{D}]
$$

In Equation 3, $C_{0}$ is the damping factor, $\dot{D}$ is the relative velocity between the two ends of the damper, $\alpha$ is the numerical power of damper velocity, and $\operatorname{sgn}$ is the sign function. Moreover, the parameters selected to define the utilized fluid viscous damper in PERFORM 3D are similar to LRBs, which are indicated in Figure 4 and Tables 2-6.

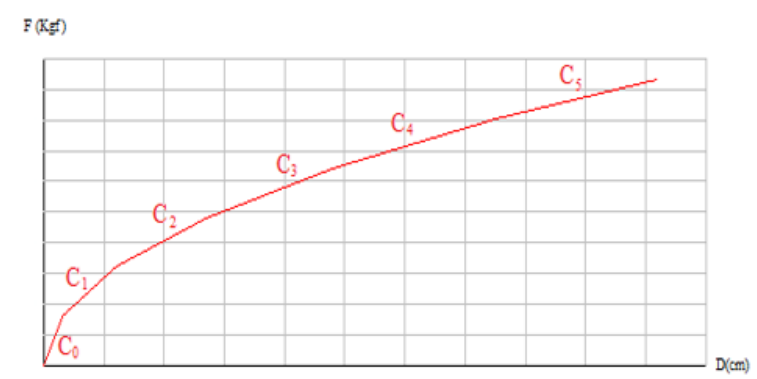

Fig. 4 - Force-displacement relationship for fluid the viscous damper the in 3-story structure

Tab. 3 - Characteristics of the fluid viscous damper in the 5-story structure

\begin{tabular}{|c|c|c|}
\hline Segment & $\begin{array}{c}\text { Deformation } \\
\text { rate }\end{array}$ & Coefficient(C) \\
\hline 1 & 0.6 & 4444 \\
\hline 2 & 2.4 & 2667 \\
\hline 3 & 5.4 & 1905 \\
\hline 4 & 9.6 & 1481 \\
\hline 5 & 15 & 1212 \\
\hline \multicolumn{2}{|c|}{$\begin{array}{c}\text { Axial Force }=\text { C (Deformation rate) } \\
\text { force at last Segment=40000Kgf }\end{array}$} \\
\hline
\end{tabular}

Tab. 2 - Characteristics of the fluid viscous damper in the 3-story structure

\begin{tabular}{|c|c|c|}
\hline Segment & $\begin{array}{c}\text { Deformation } \\
\text { rate }\end{array}$ & Coefficient(C) \\
\hline 1 & 0.6 & 2222 \\
\hline 2 & 2.4 & 1333 \\
\hline 3 & 5.4 & 952.4 \\
\hline 4 & 9.6 & 740.7 \\
\hline 5 & 15 & 606.1 \\
\hline \multicolumn{2}{|c|}{ Axial Force =C (Deformation rate) $)^{0.5}$} \\
force at last Segment=20000Kgf
\end{tabular}

Tab. 4 - Characteristics of the fluid viscous damper in the 8-story structure

\begin{tabular}{|c|c|c|}
\hline Segment & $\begin{array}{c}\text { Deformation } \\
\text { rate }\end{array}$ & Coefficient(C) \\
\hline 1 & 0.6 & 6667 \\
\hline 2 & 2.4 & 4000 \\
\hline 3 & 5.4 & 2857 \\
\hline 4 & 9.6 & 2222 \\
\hline 5 & 15 & 1818 \\
\hline \multicolumn{2}{|c|}{$\begin{array}{r}\text { Axial Force =C (Deformation rate) } \\
\text { force at last Segment=60000Kgf }\end{array}$} \\
\hline
\end{tabular}


Tab. 5: Characteristics of the fluid viscous damper in the 11-story structure

\begin{tabular}{|c|c|c|}
\hline Segment & $\begin{array}{c}\text { Deformation } \\
\text { rate }\end{array}$ & Coefficient(C) \\
\hline 1 & 0.6 & 8889 \\
\hline 2 & 2.4 & 5333 \\
\hline 3 & 5.4 & 3810 \\
\hline 4 & 9.6 & 2963 \\
\hline 5 & 15 & 2424 \\
\hline \multicolumn{2}{|c|}{$\begin{array}{c}\text { Axial Force }=\text { C (Deformation rate) })^{0.5} \\
\text { force at last Segment=80000Kgf }\end{array}$} \\
\hline
\end{tabular}

Tab. 6: Characteristics of the fluid viscous damper in the 14-story structure

\begin{tabular}{|c|c|c|}
\hline Segment & $\begin{array}{c}\text { Deformation } \\
\text { rate }\end{array}$ & Coefficient(C) \\
\hline 1 & 0.6 & 11110 \\
\hline 2 & 2.4 & 6667 \\
\hline 3 & 5.4 & 4762 \\
\hline 4 & 9.6 & 3704 \\
\hline 5 & 15 & 3030 \\
\hline \multicolumn{3}{|c|}{$\begin{array}{c}\text { Axial Force }=\text { C (Deformation rate) } \\
\text { force at last Segment }=100000 \mathrm{Kgf}\end{array}$} \\
\hline
\end{tabular}

\section{Equation of motion}

In 1999, Naeim F and Kelly JM [25] evaluated the relative displacement ( $u$ ) of each degree of freedom with respect to the ground. The equation is as follows:

$$
\mathrm{Mü}+\mathrm{Cu}+\mathrm{Ku}=-\mathrm{Mrü}_{\mathrm{g}}
$$

Where, $r$ is a vector that couples each degree of freedom to the ground motion. When this structural model is superimposed on a base isolation system with the base mass $m_{b}$, stiffness $k_{b}$, and damping $c_{b}$, Equation 4 becomes:

$$
M \ddot{v}+C \dot{v}+K v=-M r\left(\ddot{u}_{g}+\ddot{v}_{b}\right)
$$

Where $\mathrm{v}$ is the displacement relative to the base slab, and $\ddot{v}_{b}$ is the relative displacement of the base slab to the ground. Now, the overall equation of motion for the combined building and the base slab is:

$$
r^{T} M\left(\ddot{v}+r \ddot{v}_{b}+r \ddot{u}_{g}\right)+m_{b}\left(\ddot{v}_{b}+\ddot{u}_{g}\right)+c_{b} \dot{v}_{b}+c_{d} \dot{v}_{d}+k_{b} v_{b}=0
$$

In Equation 6, $v_{d}$ is the displacement relative to the fluid viscous dampers, which can be rewritten in the following form:

$$
r^{T} M \ddot{v}+\left(m+m_{b}\right) \ddot{v}_{b}+c_{b} \dot{v}_{b}+c_{d} \dot{v}_{d}+k_{b} v_{b}=-\left(m+m_{b}\right) \ddot{u}_{g}
$$

Equation 7 identifies $r^{T} M$ as the total mass $m$ of the building. Therefore, $m+m_{b}$ is the total mass carried by the isolation system. Equation 7 can be written in matrix form as follows:

$$
\begin{gathered}
\mathrm{M}^{*} \ddot{\mathrm{v}}^{*}+\mathrm{C}^{*} \dot{\mathrm{v}}^{*}+\mathrm{K}^{*} \mathrm{v}^{*}=-\mathrm{M}^{*} \mathrm{r}^{*} \ddot{\mathrm{u}}_{\mathrm{g}} \\
\mathrm{M}^{*}=\left[\begin{array}{cc}
\mathrm{m}+\mathrm{m}_{\mathrm{b}} & \mathrm{r}^{\mathrm{T}} \mathrm{M} \\
\mathrm{Mr} & \mathrm{M}
\end{array}\right] \quad \mathrm{C}^{*}=\left[\begin{array}{cc}
\mathrm{c}_{\mathrm{b}}+\mathrm{c}_{\mathrm{d}} & 0 \\
0 & \mathrm{C}
\end{array}\right] \quad \mathrm{K}^{*}=\left[\begin{array}{cc}
\mathrm{k}_{\mathrm{b}} & 0 \\
0 & \mathrm{~K}
\end{array}\right] \quad \mathrm{r}^{*}=\left[\begin{array}{l}
1 \\
0
\end{array}\right] \quad \mathrm{v}^{*}=\left[\begin{array}{c}
\mathrm{v}_{\mathrm{b}} \\
\mathrm{v}
\end{array}\right]
\end{gathered}
$$




\section{Ground motion information}

For time-history analyse by PERFORM 3D, the ground motions should be scaled such that the average value of the 5 percent damped response spectra for the suite of motions is not less than the design response spectrum of the site for periods ranging from $0.2 \mathrm{~T}$ to $1.5 \mathrm{~T}$. $\mathrm{T}$ is the fundamental period of structure in the fundamental mode for the direction of the response being analyzed (standard no. 2800) [26].

Tab. 7 - Characteristics of NF earthquake motions

\begin{tabular}{|c|c|c|c|c|c|c|c|}
\hline No. & Earthquake & $\mathbf{M}$ & Station & Distance(km) & PGA(g) & PGV(cm/s) & PGD(cm) \\
\hline 1 & Northridge & 6.69 & LA Dam & 11.79 & 0.576 & 77.09 & 20.1 \\
\hline 2 & Chi Chi & 7.62 & TCU068 & 3.01 & 0.5 & 277.56 & 715.8 \\
\hline 3 & San Fernando & 6.61 & $\begin{array}{c}\text { Pacoima } \\
\text { Dam }\end{array}$ & 11.86 & 0.827 & 34.43 & 18.67 \\
\hline 4 & Palm springs & 6.06 & $\begin{array}{c}\text { North Palm } \\
\text { springs }\end{array}$ & 10.57 & 0.669 & 73.55 & 11.87 \\
\hline 5 & Kocaeli & 7.4 & Sakarya & 3.2 & 0.41 & 82.05 & 205.9 \\
\hline 6 & Gazil & 6.8 & Karakyr & 12.82 & 0.599 & 64.94 & 24.18 \\
\hline 7 & $\begin{array}{c}\text { Whittier } \\
\text { narrows }\end{array}$ & 5.99 & $\begin{array}{c}\text { Santa-fe } \\
\text { springs }\end{array}$ & 11.73 & 0.398 & 23.75 & 1.76 \\
\hline
\end{tabular}

Tab. 8 - Characteristics of FF earthquake motions

\begin{tabular}{|l|c|c|c|c|c|c|c|}
\hline No. & Earthquake & $\mathbf{M}$ & Station & Distance(km) & PGA(g) & PGV(cm/s) & PGD(cm) \\
\hline 1 & $\begin{array}{c}\text { Imperial } \\
\text { Valley }\end{array}$ & 6.53 & Brawley Airport & 43 & 0.158 & 36.09 & 22.63 \\
\hline 2 & Loma Prieta & 6.9 & Richmond City Hall & 87.87 & 0.124 & 17.34 & 3.58 \\
\hline 3 & Tabas(Iran) & 6.8 & Tabas & 55.24 & 0.851 & 121.22 & 95.06 \\
\hline 4 & Kobe & 6.9 & KJMA & 18.27 & 0.854 & 95.75 & 24.56 \\
\hline 5 & Chi Chi & 7.62 & TCU065 & 26.67 & 0.831 & 129.55 & 93.85 \\
\hline 6 & Kocaeli & 7.51 & Sakarya & 33.24 & 0.376 & 79.49 & 70.56 \\
\hline 7 & Northridge & 6.7 & Huntington BchWaikiki & 69.5 & 0.086 & 5.01 & 1.63 \\
\hline
\end{tabular}

\section{Discussion and results}

When the time history analyses, the acceleration response, the velocity, and displacement of the classes for all of earthquakes has been discovered, it is observed that the changes in the output responses of all earthquakes are very close to each other. Therefore, only the Northridge earthquake responses are presented.

As shown in Figures 5 - 15 and Table 9, the response of the structures is extracted under near-field scaled Northridge (North. NF) and far-field scaled Northridge (North. FF) records. Hence, the reduced amounts in most displacements of the upper level of base isolation are observed according to the following Figures and tables: 


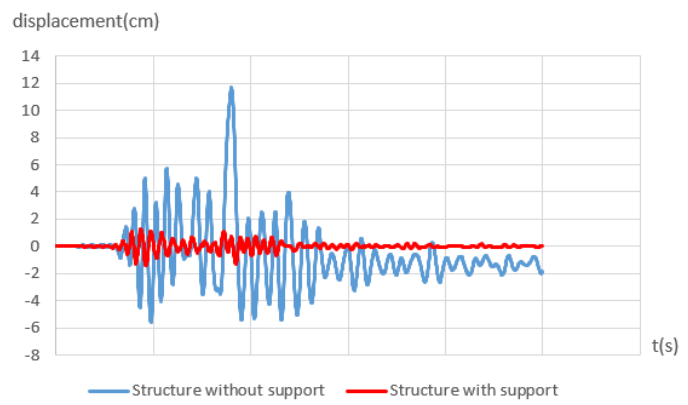

Fig. 5 - Displacement of North. FF earthquake for the 3-story structure

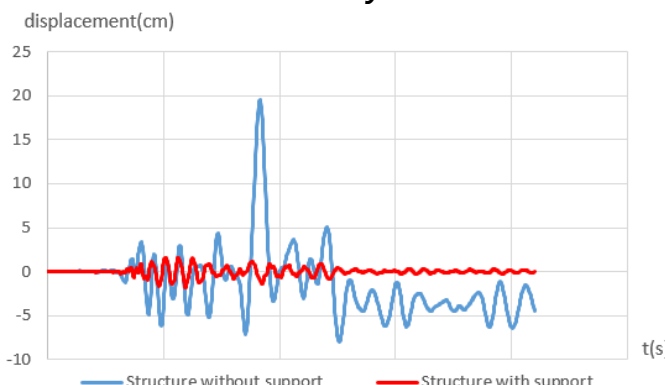

Fig. 7-Displacement of North. FF earthquake for the 5-story structure

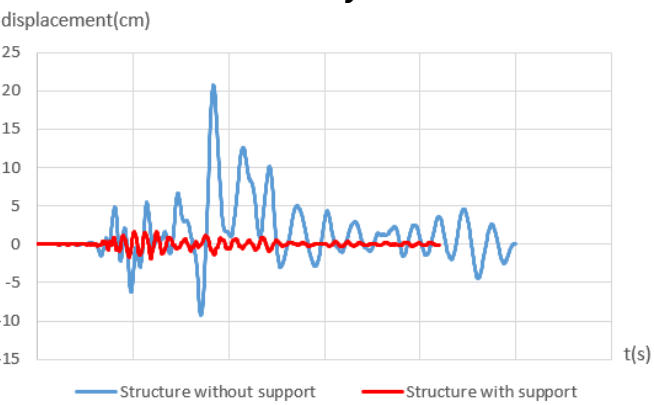

Fig. 9 - Displacement of North. FF earthquake for the 8-story structure

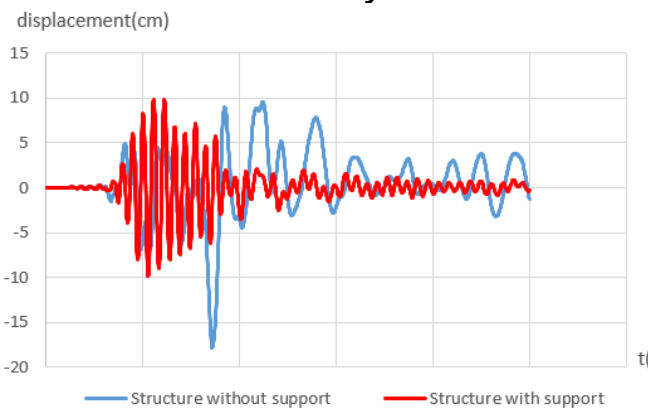

Fig. 11 - Displacement of North. FF earthquake for the 11-story structure

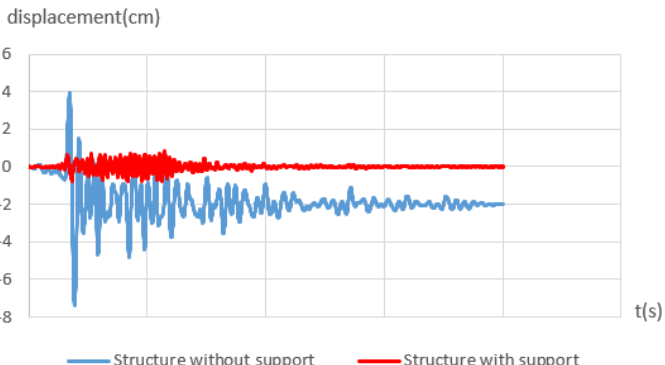

Fig. 6 - Displacement of North. NF earthquake

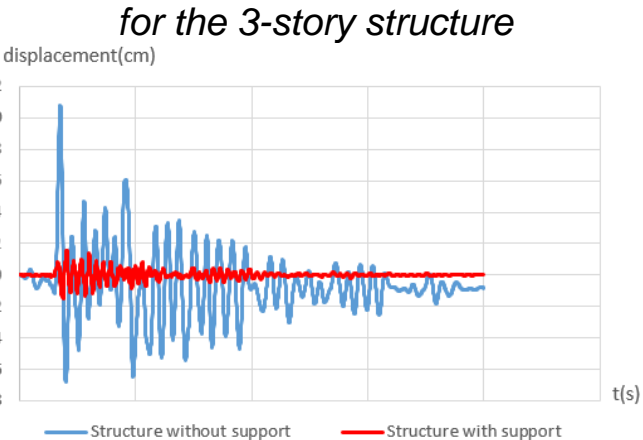

Fig. 8 - Displacement of North. NF earthquake for the 5-story structure

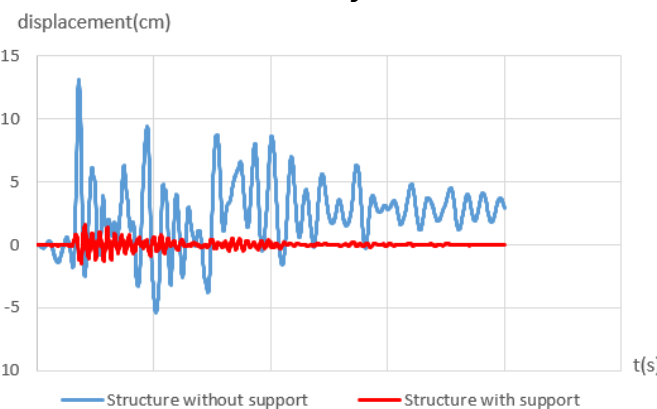

Fig. 10 - Displacement of North. NF earthquake for the 8-story structure displacement $(\mathrm{cm})$

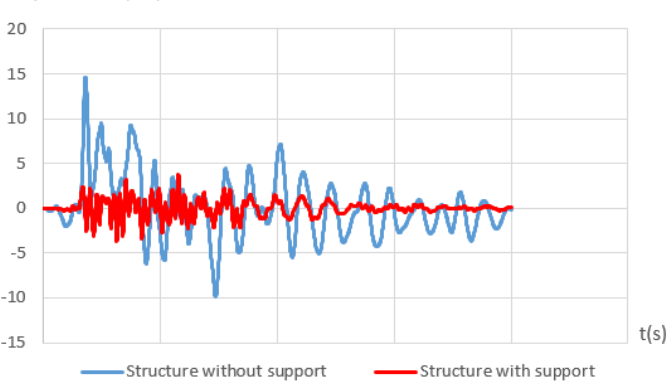

Fig. 12 - Displacement of North. NF earthquake for the 11-story structure 


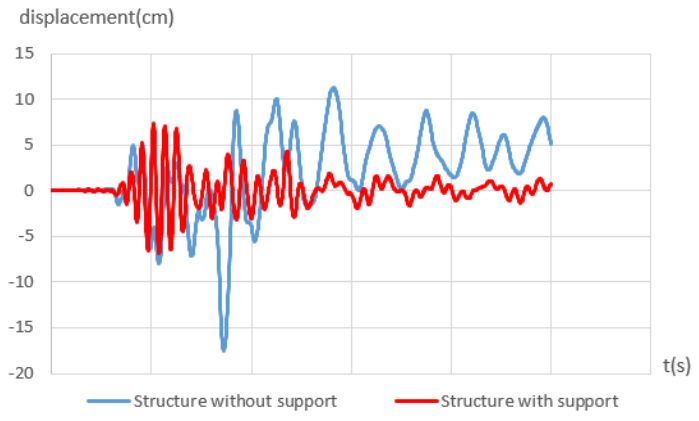

Fig. 13 - Displacement of North. FF earthquake for the 14-story structure

Tab. 9 - The reduced amounts of lateral displacement of the upper level of the base isolation in structures with rigid support under the North. FF and North. $N F$ earthquakes

\begin{tabular}{|c|c|c|}
\hline Structure & Far & Near \\
\hline 3 story & $88 \%$ & $87 \%$ \\
\hline 5 story & $90.3 \%$ & $85.6 \%$ \\
\hline 8 story & $90.6 \%$ & $84.8 \%$ \\
\hline 11 story & $44.7 \%$ & $74.5 \%$ \\
\hline 14 story & $58.3 \%$ & $77 \%$ \\
\hline
\end{tabular}

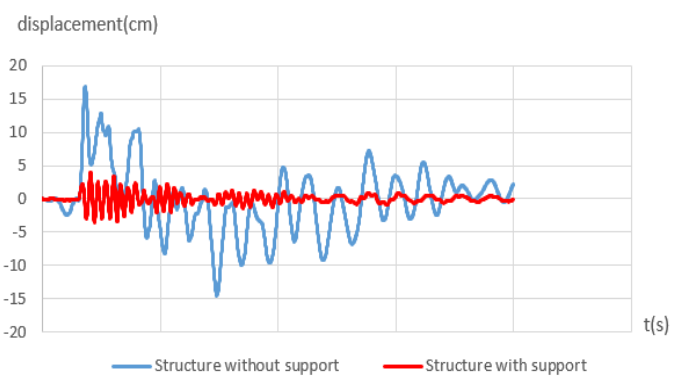

Fig. 14 - Displacement of North. NF earthquake for the 14-story structure

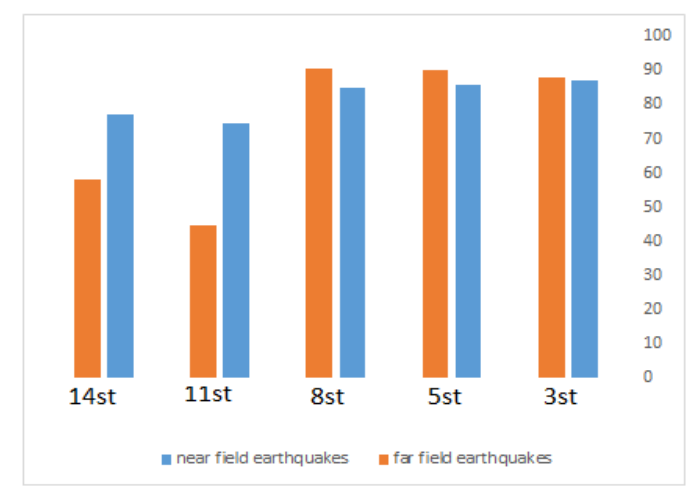

Fig. 15 - The reduced amounts of lateral displacement of the upper level of base isolation in structures with rigid support under the North. FF and North. NF earthquakes

As shown in Figures $16-26$ and Table 10, the response of these structures is extracted similar to the previous section, (North. NF) and (North. FF). Furthermore, reduced amounts in most base shears of the upper level of base isolation are observed in the following figures and tables:

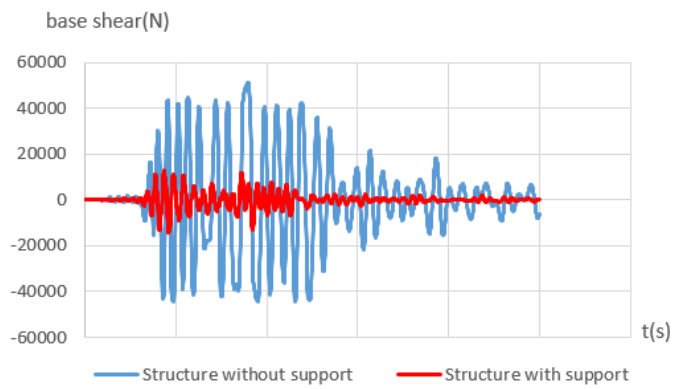

Fig. 16 - Base shear of North. FF earthquake for the 3-story structure

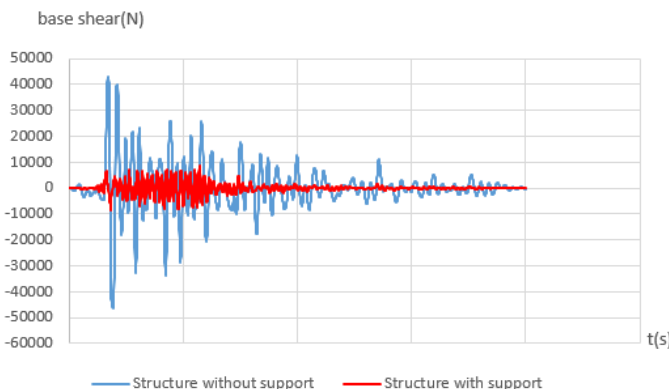

Fig. 17-Base shear of North. NF earthquake for the 3-story structure 


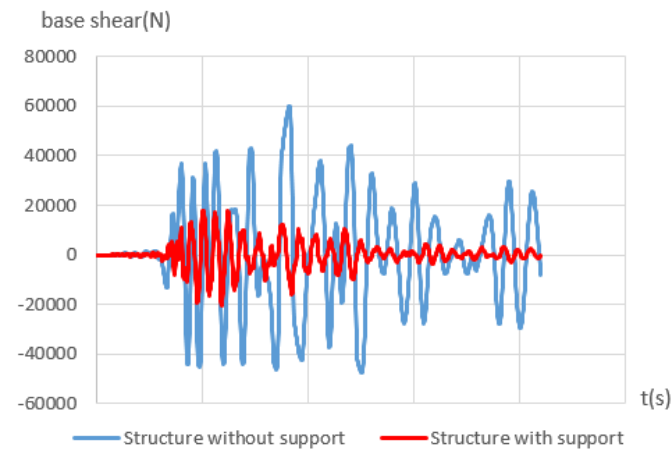

Fig. 18-Base shear of North. FF earthquake for the 5-story structure

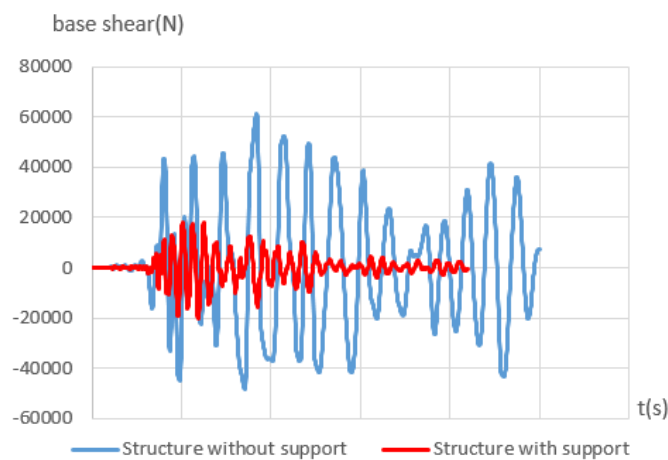

Fig. 20 - Base shear of North. FF earthquake for the 8-story structure

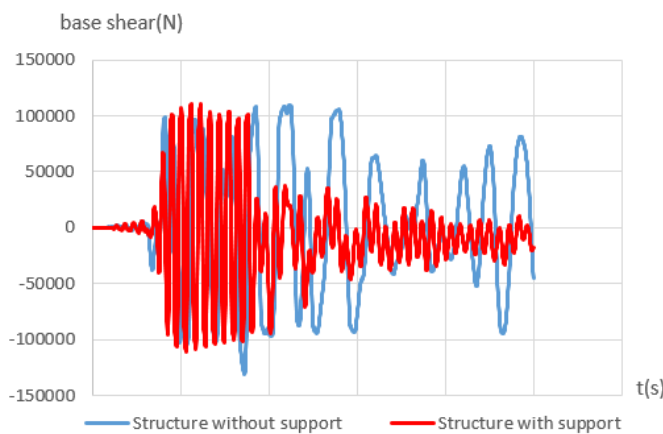

Fig. 22 - Base shear of North. FF earthquake for the 11-story structure

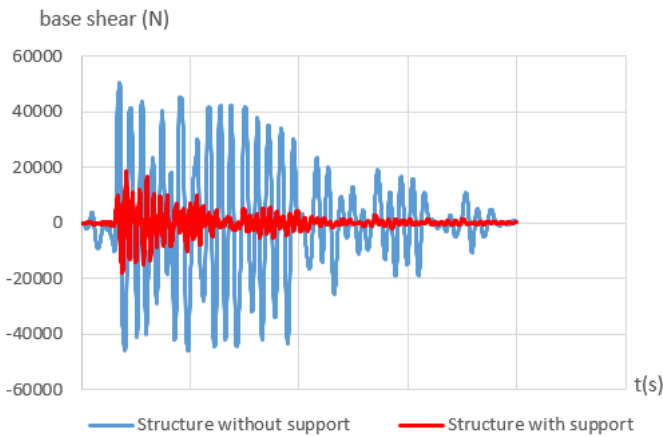

Fig. 19 - Base shear of North. NF earthquake for the 5-story structure

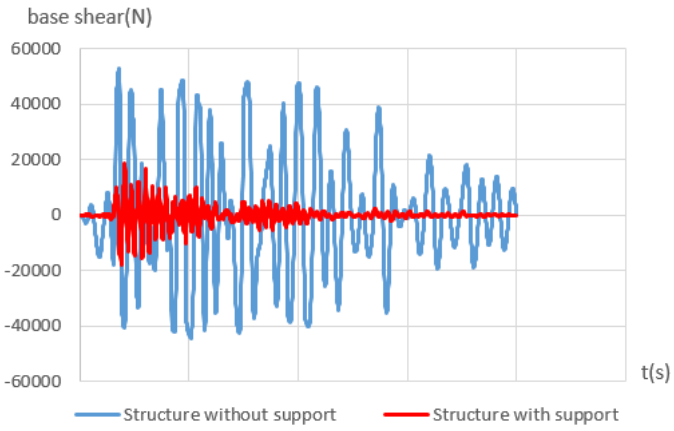

Fig. 21 - Base shear of North. NF earthquake for the 8-story structure

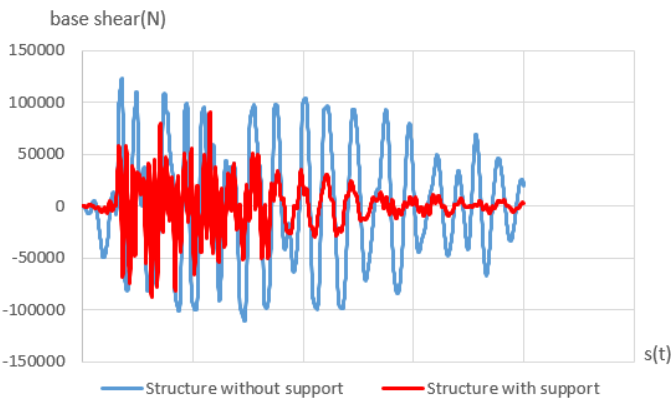

Fig. 23 - Base shear of North. NF earthquake for the 11-story structure 


\section{$\prod_{\text {CIVIL }}$ JOURNAL}

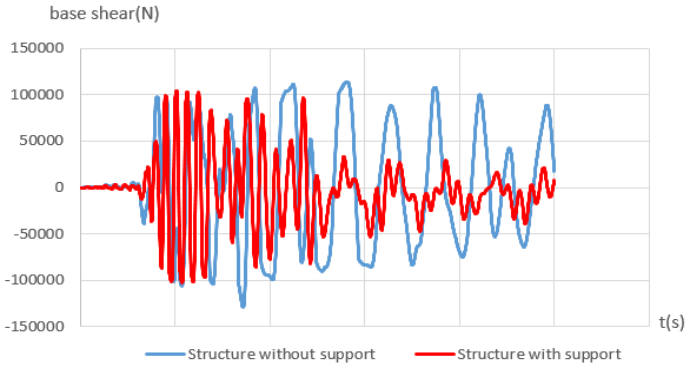

Fig. 24 - Base shear of North. FF earthquake for the 14-story structure

Tab. 10 - The reduced amounts of base shear of the upper level of base isolation in structures with rigid support under the North. FF and North. NF earthquakes

\begin{tabular}{|c|c|c|}
\hline Field & Far & Near \\
\hline Structure & & \\
\hline 3 story & $71 \%$ & $78 \%$ \\
\hline 5 story & $66 \%$ & $64 \%$ \\
\hline 8 story & $55 \%$ & $45 \%$ \\
\hline 11 story & $15 \%$ & $26 \%$ \\
\hline 14 story & $19 \%$ & $25 \%$ \\
\hline
\end{tabular}

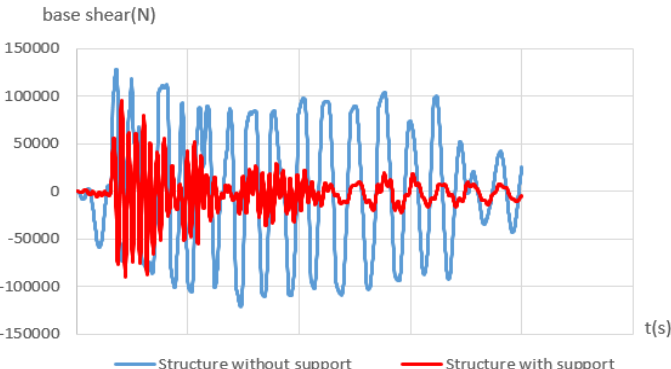

Fig. 25 - Base shear of North. NF earthquake for the 14-story structure

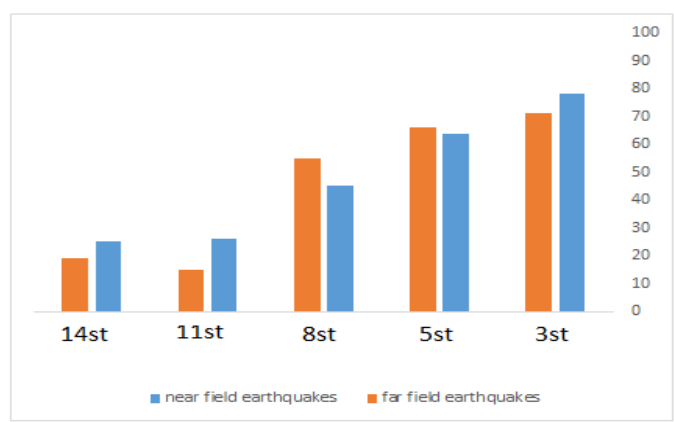

Fig. 26 - The reduced amounts of base shear of the upper level of base isolation in structures with rigid support under the North. FF and North. NF earthquakes

The results demonstrate that the structures with viscous dampers have four main advantages. The first considerable effect of support structures with viscous dampers in the nearfield earthquakes is reducing the displacement of the upper level of base isolation and decreasing the base shear in all of the structures, especially in shorter buildings. Similarly, the same effect of the mentioned structure is observed in the far-field earthquakes.

As shown in Figures 27 - 37 and Table 11, the velocity of stories in the structures is extracted as (North. NF) and (North. FF) records, and reduced amounts in the velocity of the stories were observed through the following figures and tables:

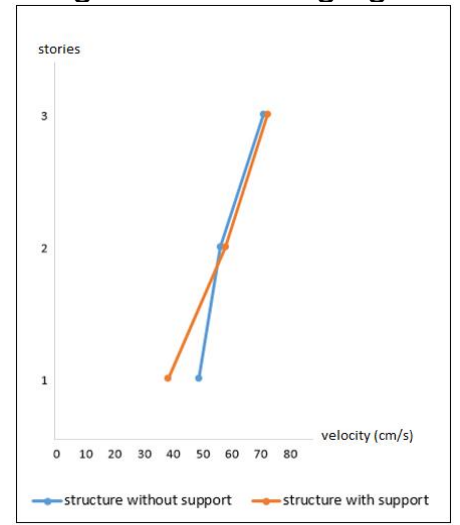

Fig. 27 - Stories velocity of North. FF earthquake for the 3-story structure

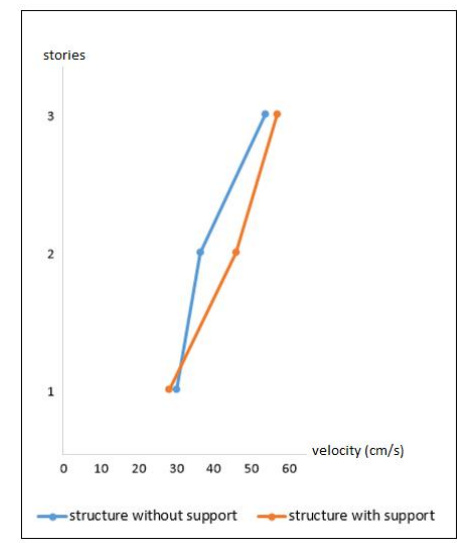

Fig. 28 - Stories velocity of North. NF earthquake for the 3-story structure 


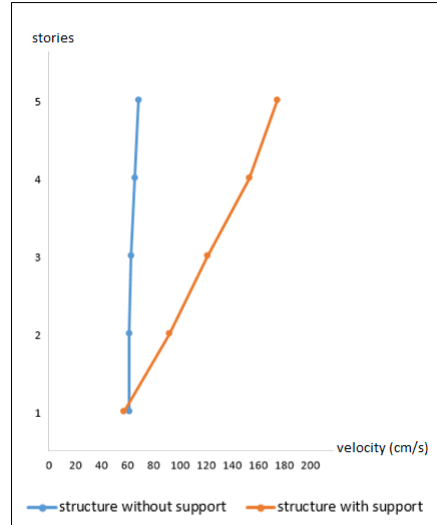

Fig. 29 - Stories velocity of North. FF earthquake for the 5-story structure

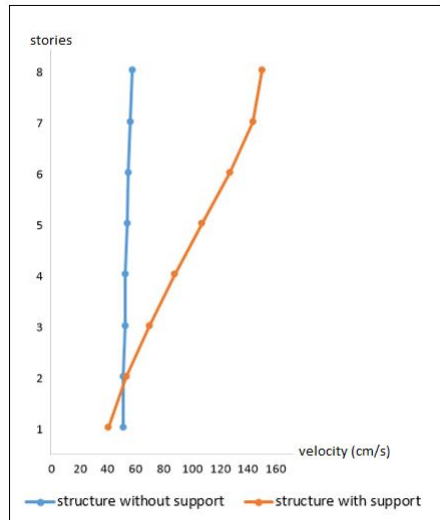

Fig. 31 - Stories velocity of North. FF earthquake for the 8-story structure

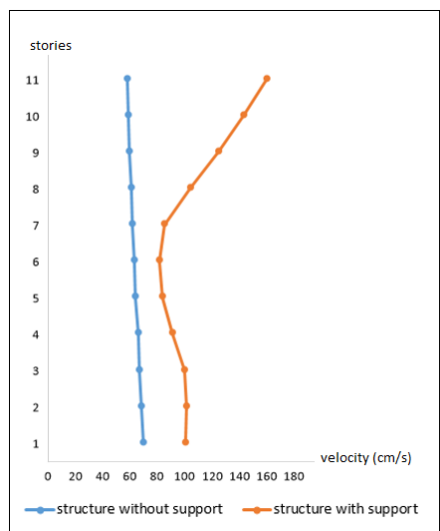

Fig. 33 - Stories velocity of North. FF earthquake for the 11-story structure

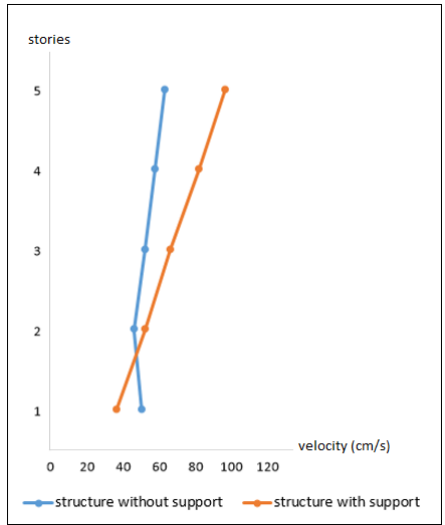

Fig. 30 - Stories velocity of North. NF earthquake for the 5-story structure

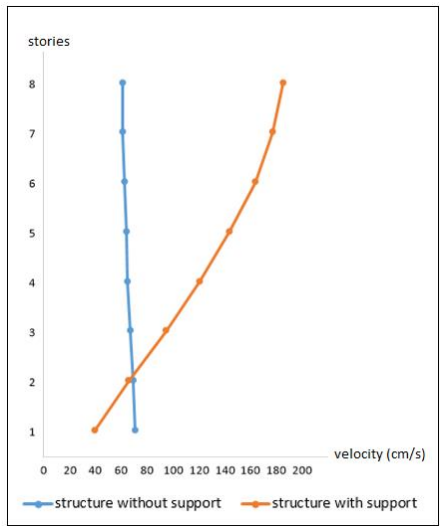

Fig. 32 - Stories velocity of North. NF earthquake for the 8-story structure

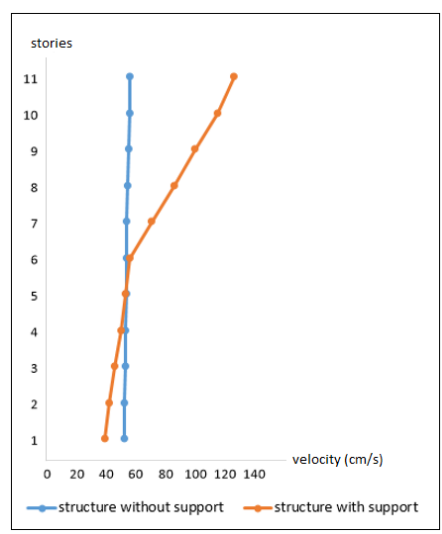

Fig. 34 - Stories velocity of North. NF earthquake for the 11-story structure 


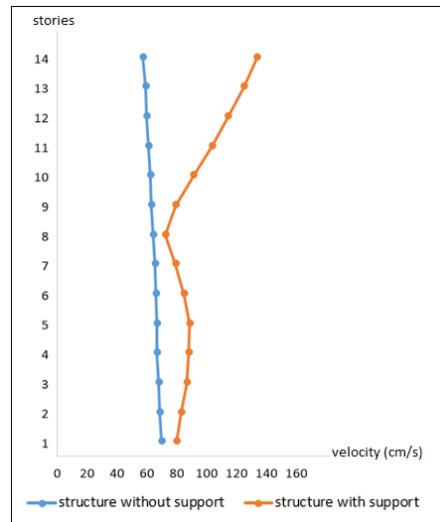

Fig. 35 - Stories velocity of North. FF earthquake for the 14-story structure

Tab. 11 - The reduced amounts of velocities in structures with rigid support under the North. FF and North. NF earthquakes

\begin{tabular}{|c|c|c|}
\hline $\begin{array}{r}\text { Field } \\
\text { Structure }\end{array}$ & Far & Near \\
\hline 3 story & $-5 \%$ & $8 \%$ \\
\hline 5 story & $86 \%$ & $23 \%$ \\
\hline 8 story & $90 \%$ & $81 \%$ \\
\hline 11 story & $68 \%$ & $32 \%$ \\
\hline 14 story & $45 \%$ & $73 \%$ \\
\hline
\end{tabular}

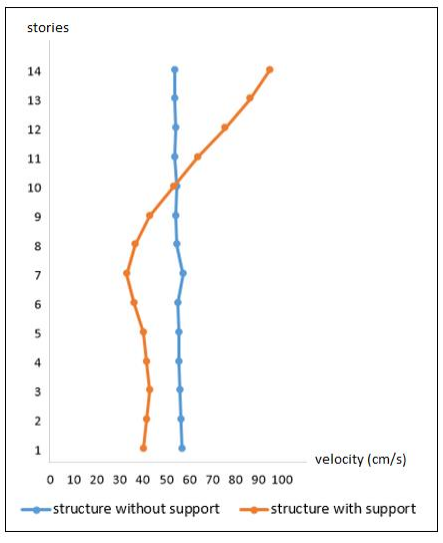

Fig. $36-$ Stories velocity of North. NF earthquake for the 14-story structure

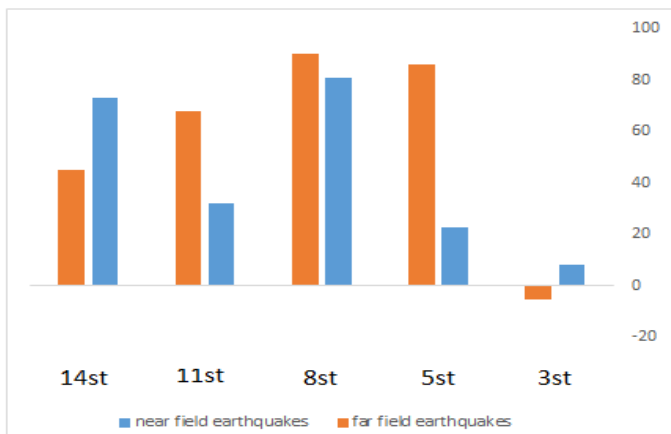

Fig. 37 - The reduction amounts of velocities in structures with rigid support under the North. FF and North. NF earthquakes

The second significant feature of support structures with viscous damper in near-field earthquakes is reducing the story velocity in all structures, especially in tall buildings. Evidently, the same effects are observed when the structure is subjected to far-field earthquakes.

As shown in Figures 38-48 and Table 12, the response of these structures is extracted as (North. NF) and (North. FF) records, and reduced amounts in the acceleration of the stories could be observed in the following figures and tables:

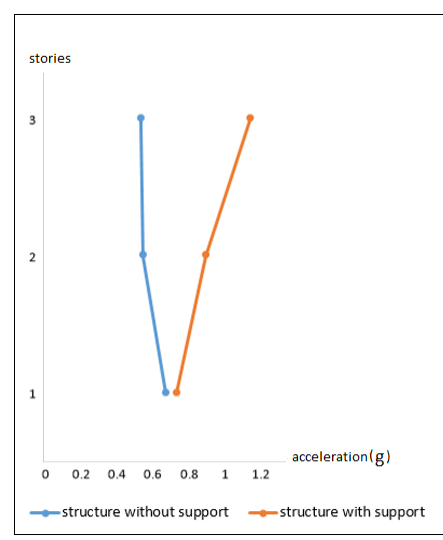

Fig. 38 - Stories acceleration of North. FF earthquake for the 3-story structure

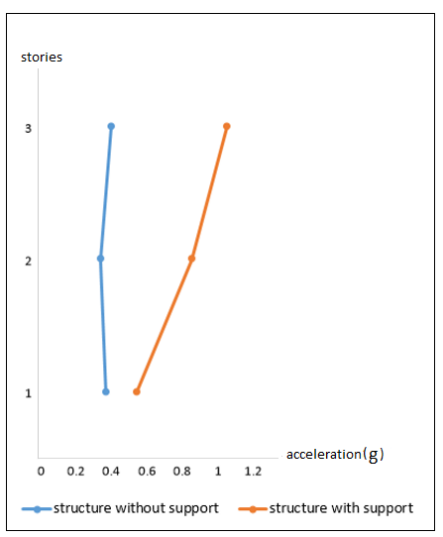

Fig. 39 - Stories acceleration of North. NF earthquake for the 3-story structure 


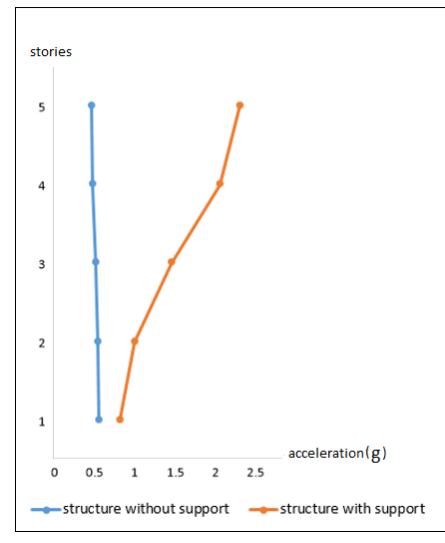

Fig. 40 - Stories acceleration of North. FF earthquake for the 5-story structure

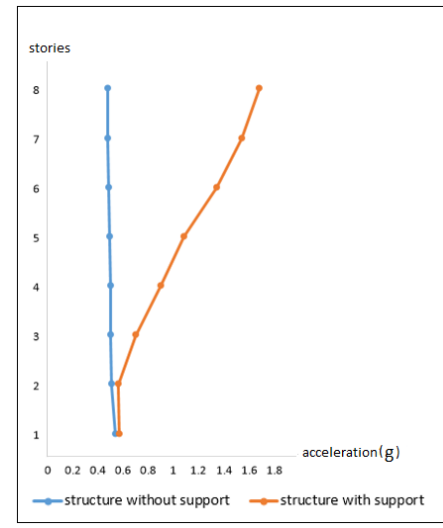

Fig. 42 - Stories acceleration of North. FF earthquake for the 8-story structure

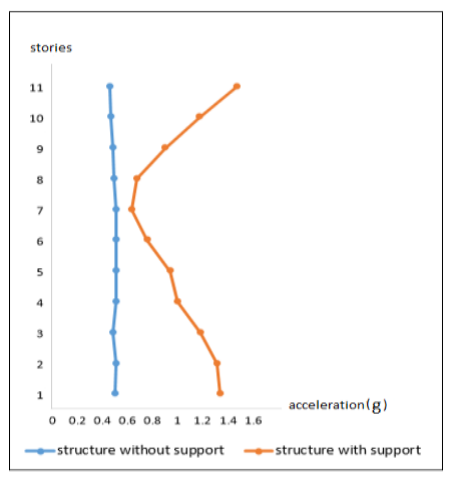

Fig. 44 - Stories acceleration of North. FF earthquake for the 11-story structure

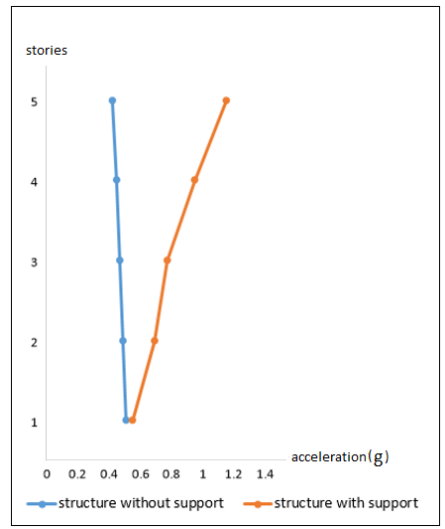

Fig. 41 - Stories acceleration of North. NF earthquake for the 5-story structure

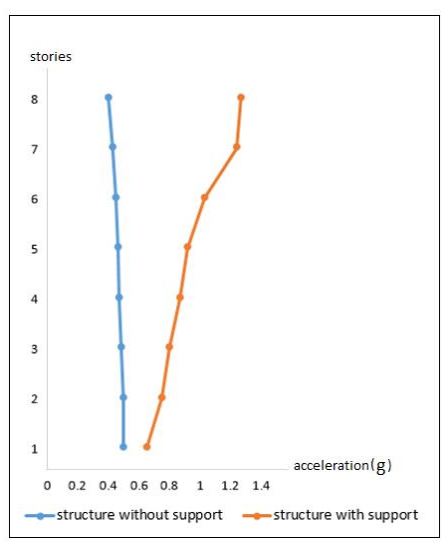

Fig. 43 - Stories acceleration of North. NF earthquake for the 8-story structure

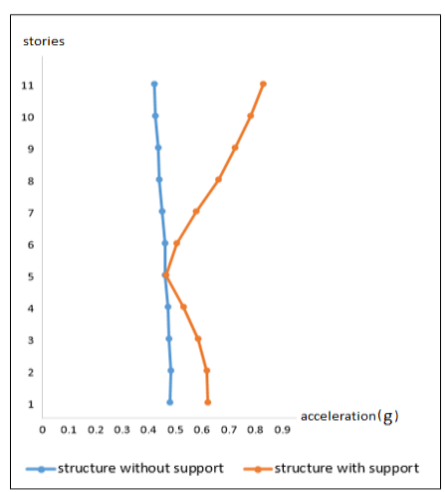

Fig. 45 - Stories acceleration of North. NF earthquake for the 11-story structure 


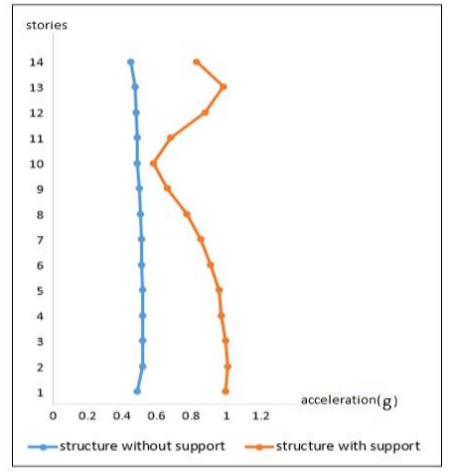

Fig. 46 - Stories acceleration of North. FF earthquake for the 14-story structure

Tab. 12 - The reduced amounts of accelerations in structures with rigid support under the North. FF and North. NF earthquakes

\begin{tabular}{|c|c|c|}
\hline $\begin{array}{r}\text { Field } \\
\text { Structure }\end{array}$ & Far & Near \\
\hline 3 story & $58 \%$ & $119 \%$ \\
\hline 5 story & $197 \%$ & $75 \%$ \\
\hline 8 story & $10 \%$ & $103 \%$ \\
\hline 11 story & $109 \%$ & $37 \%$ \\
\hline 14 story & $-6 \%$ & $6 \%$ \\
\hline
\end{tabular}

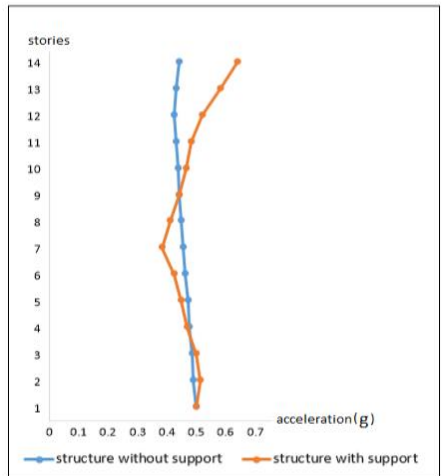

Fig. 47-Stories acceleration of North. NF earthquake for the 14-story structure

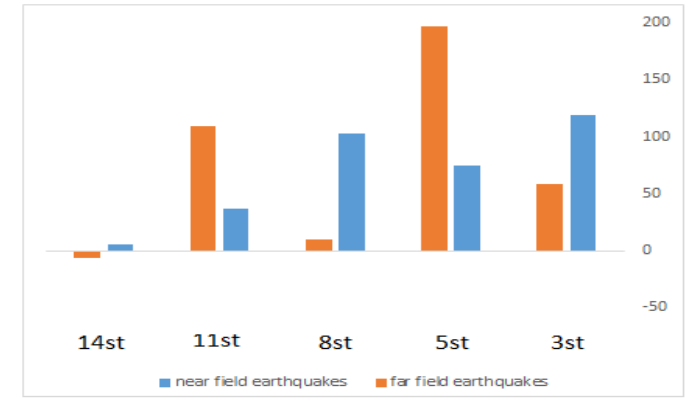

Fig. 48 - The reduced amounts of accelerations in structures with rigid support under the North. FF and North. NF earthquakes

The third vital strength of support structures with viscous damper in near-field earthquakes is reducing the stories' acceleration in all of structures, especially in short structures. The mentioned effects are also evident in all types of structure subjected to far-field earthquakes.

The fourth important advantage of the support structures with viscous dampers is changing the first modal shape of the structure from shear to torsional. This important effect plays a significant role in reducing the effect of modal mass on the first action of the structure. Despite early long pulses in near-field earthquakes records, the risk of structural collapse in base isolation is greatly reduced.

\section{CONCLUSIONS}

The base isolation is usually designed to reduce the destructive effects of an earthquake, prolong the effective life of a building, and help the structures to be similar to a rigid body. Although using a base isolation system could improve the mentioned features, in case of a near-field earthquake, it may cause a significant reduction in the structures' stability leading to the building overturn and destruction. The previous studies have demonstrated that the structure with a base isolation design usually experiences critical lateral displacement leading to the structure's overturn. Consequently, one of the main concerns in the utilization of base isolations is the inconsistent performance of the design when subjected to near-field earthquakes. Therefore, if the lateral displacement is handled properly and its amplitude is decreased enough to be safe for the structure and its residents, the application of such a system is fully justified. 


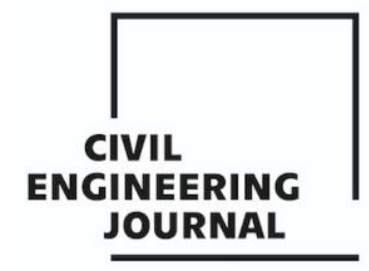

Article no. 66

THE CIVIL ENGINEERING JOURNAL 4-2021

As a remedy to the mentioned problem, in this study, a safe method for reducing the lateral displacement of base isolation under near-field earthquakes was proposed. For all the models in the study, a support structure is designed which is connected crosswise with a viscous damper to the roof, and it is rigidly connected to the foundation of the building. Analyses of the results revealed that the implementation of the proposed method has five main advantages which are as follows:

- The lateral displacement of the base isolation in all types of structures subjected to near-field earthquakes is significantly reduced.

- The base shear was proved to substantially decrease when subjected to near-field ground motions.

- The acceleration of the stories is observed to experience a major decrease as a result of the support structure in all types of buildings when subjected to near-field earthquakes.

- The velocity of the stories in the case of a near-field earthquake is remarkably dropped in all types of buildings.

- The first modal shape of the structures has shifted from shear to torsional.

These advantages demonstrate that most of the destructive effects of the resonance, which could be caused by near-field earthquakes, leading to the overturn of the buildings are eliminated. Hence, the method justifies the application of the lead rubber bearing isolation systems. Moreover, this method could help to save the structural and non-structural properties of the building, and more importantly, this method could reduce the mortality rates caused by near-field earthquakes.

\section{REFRENCES}

[1] Bolt, B.A., 1971. The San Fernando Valley, California, Earthquake of February 9 1971: Data on seismic hazards. Bulletin of the seismological society of America, 61(2), pp.501-510.

[2] Hudson, D.E. and Housner, G.W., 1958. An analysis of strong-motion accelerometer data from the San Francisco earthquake of March 22, 1957. Bulletin of the seismological society of America, 48(3), pp.253268, https://doi.org/10.1785/BSSA0480030253.

[3] Jouneghani, K.T., Hosseini, M., Rohanimanesh, M.S. and Dehkordi, M.R., 2017. Evaluating main parameters effects of near-field earthquakes on the behavior of concrete structures with moment frame system. Advances in Science and Technology. Research Journal, 11(3), https://doi.org/10.12913/22998624/74135.

[4] Lu, L.Y., Lin, C.C. and Lin, G.L., 2013. Experimental evaluation of supplemental viscous damping for a sliding isolation system under pulse-like base excitations. Journal of Sound and Vibration, 332(8), pp.19821999, https://doi.org/10.1016/i.jsv.2012.12.008.

[5] Kelly, J.M., 1999. The role of damping in seismic isolation. Earthquake engineering \& structural dynamics, 28(1), $\quad$ pp.3-20, $\quad$ https://doi.org/10.1002/(SICl)1096-9845(199901)28:1\%3C3::AIDEQE801\%3E3.0.CO;2-D.

[6] Jangid, R.S. and Kelly, J.M., 2001. Base isolation for near-fault motions. Earthquake engineering \& structural dynamics, 30(5), pp.691-707, https://doi.org/10.1002/eqe.31.

[7] Hall, J.F., 1999. The role of damping in seismic isolation. Earthquake engineering \& structural dynamics, 28(12), pp.1717-1720.

[8] Alhan, C. and Gavin, H., 2004. A parametric study of linear and non-linear passively damped seismic isolation systems for buildings. Engineering structures, 26(4), pp.485-497, https://doi.org/10.1016/j.engstruct.2003.11.004.

[9] Alhan, C. and Gavin, H.P., 2005. Reliability of base isolation for the protection of critical equipment from earthquake hazards. Engineering structures, 27(9), pp.1435-1449, https://doi.org/10.1016/i.engstruct.2005.04.007

[10] Jangid, R.S., 2007. Optimum lead-rubber isolation bearings for near-fault motions. Engineering structures, 29(10), pp.2503-2513, https://doi.org/10.1016/i.engstruct.2006.12.010.

[11] Alhan, C. and Göktaş, Y., 2009. Effects of near-field earthquakes on seismically isolated buildings. In InProceedings, WCCE-ECCE-TCCE joint conference: earthquake and tsunami (pp. 22-24). 


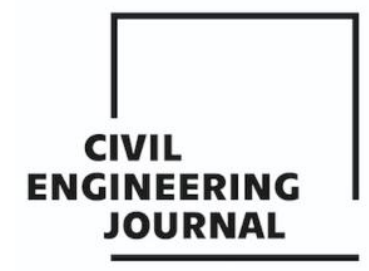

Article no. 66

THE CIVIL ENGINEERING JOURNAL 4-2021

[12] Providakis, C.P., 2009. Effect of supplemental damping on LRB and FPS seismic isolators under nearfault ground motions. Soil Dynamics and Earthquake Engineering, 29(1), pp.80-90, https://doi.org/10.1016/i.soildyn.2008.01.012.

[13] Mazza, F. and Vulcano, A., 2009. Nonlinear response of RC framed buildings with isolation and supplemental damping at the base subjected to near-fault earthquakes. Journal of Earthquake Engineering, 13(5), pp.690-715, https://doi.org/10.1080/13632460802632302.

[14] Lu, L.Y., Shih, M.H., Tzeng, S.W. and Chien, C.C., 2003, February. Experiment of a sliding isolated structure subjected to near-fault ground motion. In Proceedings of the 7th pacific conference on earthquake engineering (pp. 13-15).

[15] Matsagar, V.A. and Jangid, R.S., 2010. Impact response of torsionally coupled base-isolated structures. Journal of vibration and control, 16(11), pp.1623-1649, https://doi.org/10.1177\%2F1077546309103271.

[16] Taflanidis, A.A. and Jia, G., 2011. A simulation-based framework for risk assessment and probabilistic sensitivity analysis of base-isolated structures. Earthquake Engineering \& Structural Dynamics, 40(14), pp.1629-1651, https://doi.org/10.1002/eqe.1113.

[17] Mazza, F. and Vulcano, A., 2012. Effects of near-fault ground motions on the nonlinear dynamic response of base-isolated rc framed buildings. Earthquake Engineering \& Structural Dynamics, 41(2), pp.211232, https://doi.org/10.1002/eqe.1126.

[18] Mazza, F., Vulcano, A. and Mazza, M., 2012. Nonlinear dynamic response of RC buildings with different base isolation systems subjected to horizontal and vertical components of near-fault ground motions. The Open Construction and Building Technology Journal, 6(1), http://dx.doi.org/10.2174/1874836801206010373.

[19] Alhan, C. and Şahin, F., 2011. Protecting vibration-sensitive contents: an investigation of floor accelerations in seismically isolated buildings. Bulletin of Earthquake Engineering, 9(4), pp.1203-1226, https://doi.org/10.1007/s10518-010-9236-0.

[20] Mazza, F. and Vulcano, A., 2009. Nonlinear response of RC framed buildings with isolation and supplemental damping at the base subjected to near-fault earthquakes. Journal of Earthquake Engineering, 13(5), pp.690-715, https://doi.org/10.1080/13632460802632302.

[21] Nigdeli, S.M., Bekdaş, G. and Alhan, C., 2014. Optimization of seismic isolation systems via harmony search. Engineering optimization, 46(11), pp.1553-1569, https://doi.org/10.1080/0305215X.2013.854352.

[22] Alhan, C. and Öncü-Davas, S., 2016. Performance limits of seismically isolated buildings under nearfield earthquakes. Engineering Structures, 116, pp.83-94, https://doi.org/10.1016/j.engstruct.2016.02.043.

[23] International Code Council, "International Building Code", Section 1623, Seismically Isolated Structures, 2000.

[24] Iranian manual for structural damping system in designed and retrofitting of buildings (N.766), 2018.

[25] Naeim, F. and Kelly, J.M., 1999. Design of seismic isolated structures: from theory to practice, mechanical characteristics and modeling of isolators. New York: Wiley; p. 93-121.

[26] Interpretation of "Iranian code of practice for seismic resistant design of building (standard No. 2800, 4th edition)", 2017. 